\title{
Density of Aedes aegypti and Aedes albopictus and its association with number of residents and meteorological variables in the home environment of dengue endemic area, São Paulo, Brazil
}

Marianni de Moura Rodrigues', Gisela Rita Alvarenga Monteiro Marques ${ }^{1 *}$, Lígia Leandro Nunes Serpa', Marylene de Brito Arduino ${ }^{1}$, Júlio Cesar Voltolini ${ }^{2}$, Gerson Laurindo Barbosa ${ }^{3}$, Valmir Roberto Andrade ${ }^{4}$ and Virgília Luna Castor de Lima ${ }^{4}$

\begin{abstract}
Background: Measure the populations of Ae. aegypti and Ae. albopictus adults according to sex and location inside or outside the residence, estimate Ae. aegypti female density per house and per resident, and test the association with abiotic factors.

Methods: Adult mosquitoes were collected monthly with a hand net and portable electric catcher in the peridomiciliary and intradomiciliary premises of residences in an urban area with ongoing dengue transmission in the municipality of São Sebastião, Brazil, from February 2011 to February 2012.

Results: Of the 1,320 specimens collected, 1,311 were Ae. aegypti, and nine were Ae. albopictus. A total of 653 male and 658 female of Ae. aegypti were recorded, of which $80 \%$ were intradomiciliary. The mean density of Ae. aegypti adult females was 1.60 females/house and 0.42 females/resident. There was an association between the number of females and the number of residents in both intradomiciliary and peridomiciliary premises $\left(r^{2}=0.92 ; p<0.001\right.$ and $r^{2}=0.68 ; p<0.001$, respectively). There was an association between the number of females and the mean and total rainfall; the correlation was better in peridomiciliary premises $\left(p=0.00 ; r^{2}=77 \%\right)$ than intradomiciliary premises in both cases $\left(p=0.01 ; r^{2}=48 \%\right)$. Minimum temperature was associated in both environments, exhibiting the same coefficient of determination $\left(p=0.02 ; r^{2}=40 \%\right)$. The low frequency of Ae. albopictus (seven females and two males) did not allow for detailed evaluation.
\end{abstract}

Conclusions: Ae. aegypti is well established within the urban area studied, and the frequency of isolation is higher inside the houses. Female density was directly proportional to the number of residents in the houses. Our data show that human population density positively affects the number of Ae. aegypti females within the residence. Meteorological variables also affected mosquito populations. These data indicate a high probability of human-vector contact, increasing the possible transmission and spread of the DEN virus. Entomological indicators of adult females revealed important information complimenting what was obtained with traditional Stegomyia indices. This information should be a part of an interconnected data set for evaluating and controlling the vector.

Keywords: Aedes aegypti, Vector control, Culicidae, Dengue, Entomological indicator, Meteorological variables

\footnotetext{
* Correspondence: giselammarques@uol.com.br

${ }^{1}$ Superintendência de Controle de Endemias, Praça Coronel Vitoriano, 23

Jardim Santa Clara, Centro, Taubaté, São Paulo CEP 12020-020, Brasil

Full list of author information is available at the end of the article
} 


\section{Background}

Worldwide, Aedes aegypti is the primary vector of the virus that causes dengue, a disease that remains a serious public health problem in many tropical and subtropical countries. The control of this disease is directed towards the reduction of mosquito density in the urban environment, where it is predominantly found because it is a highly synanthropic species and has a blood-feeding preference for humans [1]. The endophilic and endophagic behaviour of Ae. aegypti adults, which can be found throughout the residential environment, is directly implicated in the successful transmission of the virus $[1,2]$.

Ae. albopictus, a homologous species that is sympatrically distributed with Ae. aegypti, is epidemiologically important in transmitting the DEN virus throughout areas of Southeast Asia, and its vector competence is recognized in different areas, including Brazil [3].

Ae. aegypti surveillance is recommended by the WHO and adopted in many dengue-endemic countries to provide a quantifiable measurement of fluctuations in the magnitude and geographical distribution of the vector population [4]. The dengue control program employed in Brazil aims to collect larvae of this species in urban areas to estimate larval density. However, several authors have reported that larval indices do not meet the epidemic alert principle [5-7]. According to Focks [8], Barata et al. [9], Resende et al. [10], and Bowman et al. [11], the mosquito's adult life cycle phase is most associated with transmission, and the female is the vector.

Several studies propose methods and indices to estimate the density of Ae. aegypti adult females [11-13]. These results have allowed the estimation of dengue's critical thresholds and allowed for better understanding of its transmission dynamics, because monitoring the abundance of adult females highlights their distribution and density, which contribute to the development of control strategies.

Climatic factors are important in the dynamics of these insects and in the epidemiology of the diseases they transmit $[14,15]$. Mosquito life cycle parameters can be affected by abiotic factors, such as temperature, which affects egg viability; larval development; longevity; and adult dispersal, whereas rainfall affects the abundance and productivity of the breeding sites of these vectors [16]. In San Juan, Puerto Rico, the temporal dynamics of Ae. aegypti was positively associated with rainfall and temperature [17].

The adaptability of Ae. aegypti to more differentiated environments inhabited by humans reinforces the need for studies focusing on the behaviour of the adult female population within residences. Thus, it is important to evaluate the presence, distribution, and abundance of the adult forms of these vectors and their relationship with the human population; entomological indicators of this mosquito phase are essential parameters to better understand this vector's ecology.

Thus, the present study aimed to investigate the abundance of the adult forms of Ae. aegypti and Ae. albopictus according to sex and location inside or outside houses in an urban area in a dengue-endemic municipality, to estimate the density of Ae. aegypti adult females per house and per resident, and to test their association with abiotic factors.

\section{Methods}

This study was conducted from February 2011 to February 2012 in the São Sebastião municipality belonging to the northern coast of São Paulo State, Brazil. This municipality includes 73,833 inhabitants and is located at $45^{\circ} 21^{\prime} 00^{\prime \prime} \mathrm{W}$ $23^{\circ} 21^{\prime} 20^{\prime \prime} \mathrm{S}$ at an altitude of $15 \mathrm{~m}$; it is $209 \mathrm{~km}$ from the capital. São Sebastião has a hot and humid climate with a mean annual temperature of approximately $20^{\circ} \mathrm{C}$ [18]. Its land area comprises $400 \mathrm{~km}^{2}$, of which approximately $300 \mathrm{~km}^{2}$ are covered by the Atlantic Forest biome.

The area studied in 2010 contained 13 neighbourhoods comprising 532 blocks consisting of 16,833 houses occupied by 40,116 inhabitants [18]. The selection of the blocks studied $(n=307)$ followed the method for random sampling of existing buildings within an urban area, according to the Manual on Entomological Surveillance for Ae. aegypti of the São Paulo State Secretary of Health (Secretaria de Saúde do Estado de São Paulo) for evaluating larval density [19]; residences were considered sampling units.

The municipality has been completely infested by $A e$. aegypti and Ae. albopictus since the late 1990s [20]. In 2001, autochthonous dengue transmission began within the referenced area and continues to date [21].

Adults were collected once monthly, surveying a mean of 156 houses/month for five consecutive days. The collection method involved searching for adult forms in intradomiciliary and peridomiciliary premises of the houses using a hand net and aspirator, according to the method described by Nasci [22].

The fieldwork team comprised four operators; one pair surveyed intradomiciliary premises simultaneously as the other surveyed peridomiciliary premises. The mosquitoes were collected for 20 minutes per house in both environments at resting sites, such as furniture, clothes, curtains, etc. $[12,23]$. After collection in each house, the mosquitoes were transferred into appropriate tubes, and the samples were sent to the laboratory for identification [23].

In each block, work was initiated at the first house located on the northernmost corner. A sampling interval of three houses (survey one and skip two) was adopted, which corresponds to approximately $30 \%$ of the residences in each block; this procedure always occurred in a clockwise direction. 
For analysing data, the STATISTICA program (version 7.0) was used with an alpha value of 0.05 after testing for normality (Shapiro-Wilk test) and homoscedasticity (Levene test). Two independent proportions tests were used to test the frequency of the adult individuals of each species. Simple linear regression analysis was used to establish the association between the number of $A e$. aegypti adult females and abiotic variables (total rainfall, mean rainfall, mean temperature, maximum temperature, and minimum temperature). The following entomological indicators were calculated for Ae. aegypti females: adult house index (AHI) [5,12,23], adult female density/house $(\mathrm{F} / \mathrm{H})[12,23,24]$, and adult female density/resident (F/R) $[23,25]$.

Daily meteorological data were obtained from the Centro Integrado de Informações Agrometeorológicas da Secretaria de Agricultura do Governo do Estado de São Paulo - CIIAGRO/SP.

\section{Results}

A total of 2,036 houses were surveyed, and 1,320 adult mosquitoes were collected. Of these, 1,311 were Ae. aegypti (658 females and 653 males), and nine were $A e$. albopictus (seven females and two males).

The number of Ae. aegypti specimens varied according to the residential environment throughout the study. Females and males of this species were more abundant in intradomiciliary premises $(\mathrm{p}=0.00)$. However, no significant difference in sex was found in any residential environment (intradomiciliary premises, $\mathrm{p}=0.53$; peridomiciliary premises, $\mathrm{p}=0.16$ ) (Table 1 ).

Table 2 shows the monthly distribution of blocks and houses surveyed and those positive for Ae. aegypti adult females. There was a total of $174(56.68 \%)$ positive blocks identified during the 13 months of study. The mean was $57.22 \%$, ranging from $100 \%$ in March to $23 \%$ in September. Of the 2,036 houses, 367 contained Ae. aegypti, with a

Table 1 Aedes aegypti and Aedes albopictus according to sex and residential environment

\begin{tabular}{|c|c|c|c|c|c|c|}
\hline \multirow[t]{2}{*}{ Location } & \multicolumn{2}{|c|}{ Intradomiciliary } & \multicolumn{2}{|c|}{ Peridomiciliary } & \multicolumn{2}{|l|}{ Total } \\
\hline & $\mathbf{N}$ & $\%$ & $\mathbf{N}$ & $\%$ & $\mathbf{N}$ & $\%$ \\
\hline \multicolumn{7}{|c|}{ Aedes aegypti } \\
\hline Females & 513 & 77.96 & 145 & 22.04 & 658 & 100.00 \\
\hline Males & 484 & 74.12 & 169 & 25.88 & 653 & 100.00 \\
\hline Subtotal & 997 & 76.05 & 314 & 23.95 & 1,311 & 100.00 \\
\hline \multicolumn{7}{|c|}{ Aedes albopictus } \\
\hline Females & 2 & 28.57 & 5 & 71.43 & 7 & 100.00 \\
\hline Males & 2 & 100.00 & 0 & 0.00 & 2 & 100.00 \\
\hline Subtotal & 4 & 44.44 & 5 & 55.56 & 9 & 100.00 \\
\hline Total & 1,001 & 75.83 & 319 & 24.17 & 1,320 & 100.00 \\
\hline
\end{tabular}

São Sebastião, northern coast of São Paulo, Brazil, February 2011 to February 2012. monthly mean of $17.76 \%$, ranging from $47.83 \%$ in March to $6 \%$ in September.

The numbers of Ae. aegypti adult females per positive house and per house surveyed are shown by month in Table 3. The number of females/month varied in both cases, exhibiting mean densities of 0.32 and 1.60 females/ house, respectively. The highest value was in March, and the lowest numbers were found in June and July.

The number of females/resident $(F / R)$ in the positive houses surveyed ranged from 0.27 in August to 0.64 in January and from 0.02 from July through September to 0.27 in March. The mean females/resident during the period studied was 0.09 in all houses surveyed and 0.42 in the positive houses (Table 4).

Figure 1 displays the association between the number of Ae. aegypti females captured in intradomiciliary and peridomiciliary premises and the number of residents per household. Our results show that this association was greater in intradomiciliary premises $\left(r^{2}=0.92\right)$.

The correlation analyses between the numbers of $A e$. aegypti adult females and abiotic factors indicated correlations with mean rainfall, total rainfall, and the number of adult individuals in both intradomiciliary $\left(\mathrm{p}=0.00 ; \mathrm{r}^{2}=77 \%\right)$ and peridomiciliary premises $(\mathrm{p}=0.01$; $\mathrm{r}^{2}=48 \%$ ) (Figure $2 \mathrm{~A}$ and $\mathrm{B}$ ). The minimum temperature revealed an association with the number of females $(\mathrm{p}=0.02)$; however, the same coefficient of determination $\left(r^{2}=40 \%\right)$ was found for both environments (Figure 2C).

The total number of Ae. albopictus collected during the 13 months of study was very low $(n=9)$; five females were captured in peridomiciliary premises, and two females and two males were collected in intradomiciliary premises, thus preventing more detailed statistical analysis (Table 1).

\section{Discussion}

In the present study, Ae. aegypti was more frequently encountered than Ae. albopictus. According to Forattini, [26] the urban environment favours Ae. aegypti, whereas rural and suburban areas favour Ae. albopictus. This environmental influence may be related to the ecology, biology, and behaviour of these species, which have distinct characteristics despite sharing other qualities.

The higher abundance of Ae. aegypti males and females in intradomiciliary premises corroborates reports in the scientific literature [2,27]. The presence of males in this environment is likely primarily related to the availability of shelter, because after emergence, the adult searches for sites with hiding places, where it can remain at rest during the period preceding the onset of activities [26].

The urban environment favours Ae. aegypti, which allows the females to feed on human blood within houses (anthropophily and endophagy). Additionally, these adults can oviposit and shelter themselves there (endophily). 
Table 2 Number of blocks and searched houses and positive for Aedes aegypti females

\begin{tabular}{|c|c|c|c|c|c|c|}
\hline \multirow[t]{2}{*}{ Month } & \multicolumn{2}{|c|}{ Number of blocks } & \multirow{2}{*}{$\begin{array}{l}\% \text { block } \\
\text { positivity }\end{array}$} & \multicolumn{2}{|c|}{ Number of houses } & \multirow[t]{2}{*}{ AHI } \\
\hline & Surveyed & Positive & & Surveyed & Positive & \\
\hline Feb & 23 & 16 & 69.57 & 170 & 41 & 24.12 \\
\hline Mar & 19 & 19 & 100.00 & 159 & 76 & 47.80 \\
\hline Apr & 21 & 19 & 90.48 & 170 & 41 & 24.12 \\
\hline May & 20 & 12 & 60.00 & 164 & 26 & 15.85 \\
\hline Jun & 23 & 11 & 47.83 & 128 & 12 & 9.38 \\
\hline Jul & 25 & 10 & 40.00 & 155 & 12 & 7.74 \\
\hline Aug & 19 & 6 & 31.58 & 159 & 12 & 7.55 \\
\hline Sep & 23 & 5 & 21.74 & 150 & 9 & 6.00 \\
\hline Oct & 26 & 11 & 42.31 & 150 & 17 & 11.33 \\
\hline Nov & 28 & 18 & 64.29 & 152 & 32 & 21.05 \\
\hline Dec & 31 & 18 & 58.06 & 166 & 32 & 19.28 \\
\hline Jan & 26 & 16 & 61.54 & 149 & 32 & 21.48 \\
\hline Feb & 23 & 13 & 56.52 & 164 & 25 & 15.24 \\
\hline Total & 307 & 174 & 56.68 & 2,036 & 367 & 18.03 \\
\hline Mean & 23.62 & 13.38 & 57.22 & 156.62 & 28.23 & 17.76 \\
\hline Standard error & 0.98 & 1.31 & 6.04 & 3.16 & 5.03 & 3.07 \\
\hline
\end{tabular}

São Sebastião, northern coast of São Paulo State, Brazil, February 2011 to February 2012.

Several authors have reported this behaviour, which favours intradomiciliary premises for breeding grounds and the deposit of eggs $[9,28,29]$. Our data confirm previous findings on the bio-ecology of this species in an urban area, supporting the use of teams for the surveillance and control of adult forms of the vector in houses.
Entomological surveillance uses diverse indices to measure the levels of Ae aegypti urban infestation. However, indices based on actual counts of the number of adult females are more accurate $[8,10,30]$. In the present study, the adult house index (AHI) showed Ae. aegypti female presence every month of the study in the

Table 3 Number of Aedes aegypti adult females and female density/house (F/H)

\begin{tabular}{|c|c|c|c|c|c|}
\hline \multirow[t]{2}{*}{ Month } & \multirow{2}{*}{$\begin{array}{l}\text { No. of } A e \text {. } \\
\text { aegypti females }\end{array}$} & \multicolumn{2}{|c|}{ Number of houses } & \multicolumn{2}{|c|}{ Female density/house $(\mathrm{F} / \mathrm{H})$} \\
\hline & & Surveyed & Positive & Surveyed & Positive \\
\hline Feb & 83 & 170 & 41 & 0.49 & 2.02 \\
\hline Mar & 175 & 159 & 76 & 1.10 & 2.30 \\
\hline Apr & 65 & 170 & 41 & 0.38 & 1.59 \\
\hline May & 48 & 164 & 26 & 0.29 & 1.85 \\
\hline Jun & 13 & 128 & 12 & 0.10 & 1.08 \\
\hline Jul & 13 & 155 & 12 & 0.08 & 1.08 \\
\hline Aug & 16 & 159 & 12 & 0.10 & 1.33 \\
\hline Sep & 11 & 150 & 9 & 0.07 & 1.22 \\
\hline Oct & 25 & 150 & 17 & 0.17 & 1.47 \\
\hline Nov & 50 & 152 & 32 & 0.33 & 1.56 \\
\hline Dec & 55 & 166 & 32 & 0.33 & 1.72 \\
\hline Jan & 65 & 149 & 32 & 0.44 & 2.03 \\
\hline Feb & 39 & 164 & 25 & 0.24 & 1.56 \\
\hline Total & 658 & 2,036 & 367 & 4.12 & 20.81 \\
\hline Mean & 50.62 & 156.62 & 28.23 & 0.32 & 1.60 \\
\hline Standard error & 12.23 & 3.16 & 5.03 & 0.08 & 0.10 \\
\hline
\end{tabular}

São Sebastião, northern coast of São Paulo State, Brazil, February 2011 to February 2012. 
Table 4 Monthly number of Aedes aegypti adult females/resident (F/R)

\begin{tabular}{|c|c|c|c|c|c|}
\hline \multirow[t]{2}{*}{ Month } & \multirow{2}{*}{$\begin{array}{l}\mathrm{N}^{\circ} \text { of } A e . \\
\text { aegypti females }\end{array}$} & \multicolumn{2}{|c|}{ Total number of residents } & \multicolumn{2}{|c|}{$\mathrm{N}^{\circ}$ of females/resident (F/R) } \\
\hline & & Surveyed houses & Positive houses & Surveyed houses & Positive houses \\
\hline Feb & 83 & 598 & 138 & 0.14 & 0.60 \\
\hline Mar & 175 & 638 & 278 & 0.27 & 0.63 \\
\hline Apr & 65 & 748 & 196 & 0.09 & 0.33 \\
\hline May & 48 & 579 & 102 & 0.08 & 0.47 \\
\hline Jun & 13 & 467 & 34 & 0.03 & 0.38 \\
\hline Jul & 13 & 541 & 46 & 0.02 & 0.28 \\
\hline Aug & 16 & 679 & 60 & 0.02 & 0.27 \\
\hline Sep & 11 & 499 & 36 & 0.02 & 0.31 \\
\hline Oct & 25 & 697 & 63 & 0.04 & 0.40 \\
\hline Nov & 50 & 537 & 140 & 0.09 & 0.36 \\
\hline Dec & 55 & 560 & 143 & 0.10 & 0.38 \\
\hline Jan & 65 & 464 & 101 & 0.14 & 0.64 \\
\hline Feb & 39 & 542 & 89 & 0.07 & 0.44 \\
\hline Total & 658 & 7,549 & 1,426 & 1.11 & 5.48 \\
\hline Mean & 50.61 & 580.69 & 109.69 & 0.09 & 0.42 \\
\hline Standard error & 12.23 & 24.47 & 19.45 & 0.02 & 0.04 \\
\hline
\end{tabular}

São Sebastião, northern coast of São Paulo State, Brazil, February 2011 to February 2012.

blocks and residences surveyed, although different percentages were found, characterizing the distribution of the species in the urban environment. One explanation can be attributed to the aggregated distribution pattern of this Stegomyia, i.e., in finding individuals of the referenced species in a particular location, it is very likely to encounter others in surrounding areas [31-33].

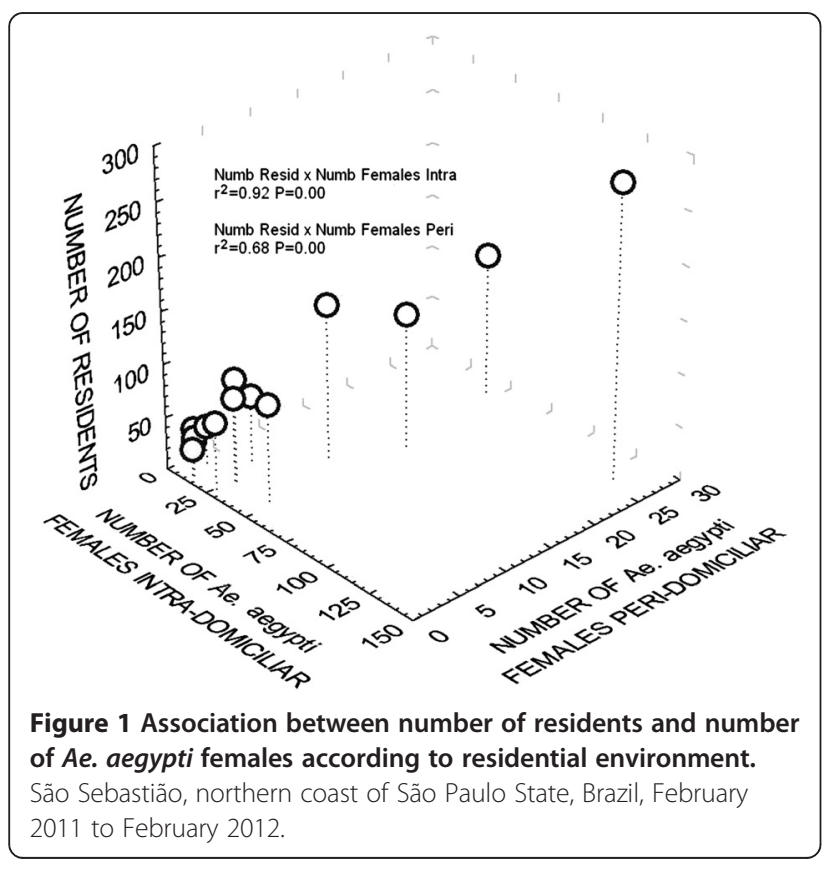

The displacement of Ae. aegypti females seems to be associated with heterogeneity in the availability of blood and containers for laying eggs. According to Harrington et al., [34], the dispersal of these females is reduced in areas with physical and/or geographic barriers that limit their flight from 50 to 300 meters over their entire lives, which means that they would not often migrate beyond the block where they initiated their activities. When females find necessary resources near their point of origin, they most likely do not migrate large distances $[6,26]$.

Gomes et al. [5] estimated house infestation in Foz do Iguaçu, Paraná, using the adult trap. They reported that Ae. aegypti was present in $9.6 \%$ of 6,661 residences surveyed. Although the same capturing method was not used, positivity also referred to the presence of females of this species. Nguyen et al. [12], in a cross-sectional descriptive study performed in Vietnam, reported that Ae. aegypti was present in $63 \%(n=76)$ of the houses visited.

The female density values in the houses surveyed $(\mathrm{F} / \mathrm{H})$ in our study were close to those found by several authors. Chan [35] reported 0.2 females/house as a threshold for dengue occurrence in Singapore. Barata et al. [36] captured 0.4 females/house in São José do Rio Preto (SP), Brazil. Barata et al., [9] in the municipality of Ocauçu and Uchoa (SP), captured 0.4 and 0.7 females/house, respectively, with resting boxes. Fávaro et al. [28], in studying density in two areas of Mirassol (SP), Brazil, reported that the mean number of females captured with aspirators ranged from 0.05 to 0.46 and from 0.08 to 0.62 at areas $\mathrm{A}$ and $\mathrm{B}$, respectively. Nguyen et al. 

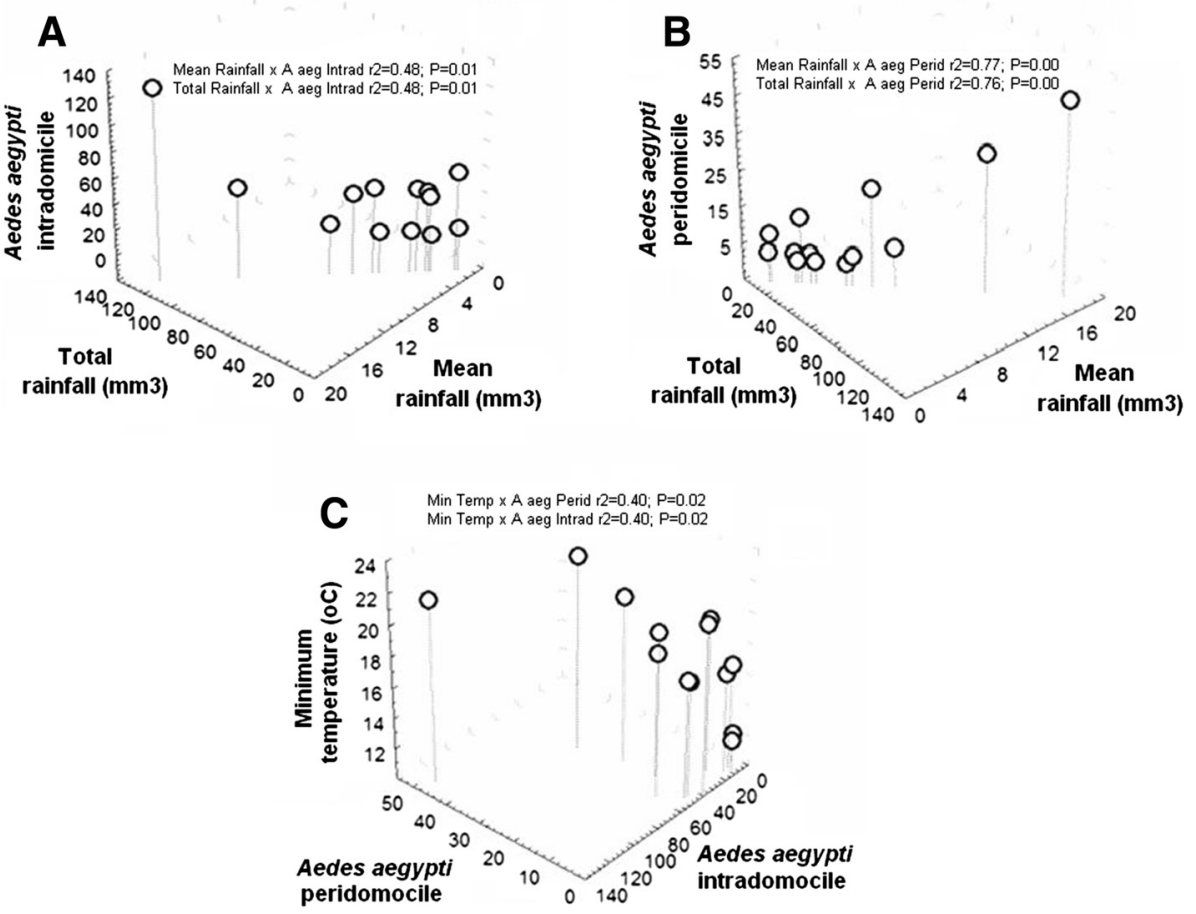

Figure 2 Association between number of Ae. aegypti females and abiotic data. A. Mean rain fall and total rain fall X Ae. aegypti in intradomicile. B. Mean rain fall and total rain fall X Ae. aegypti in peridomicile. C. Minimum temperature X Ae. aegypti in peridomicile and intradomicile.

[12] used aspirators and found a density of 1.8 females/ house in South Vietnam.

Females of this species are fast and persistent suckers capable of ingesting blood multiple times during a single gonotrophic cycle, a behaviour that increases the possibility of infecting and transmitting DEN viruses [26,37]. Dengue virus infection events were reported in areas with low densities of this mosquito [37,38]. Thus, performing studies that consider the population density of Ae. aegypti adult females transmitting dengue to show the quantitative relationship between vector indices and dengue cases could define a confidence level that could be used as a warning of impending dengue transmission; this may have been a limiting factor in this study.

Another important indicator of the risk of dengue transmission is related to human density and the number of Ae. aegypti females. This human-vector proximity has been reported by different authors. Chen et al. [39], in a study in Taiwan, showed a density of 0.07 females/ person. Other authors in Colombia found 0.5 females/ person [23]. In Trinidad, Chadee [40] found values of 0.6-0.7 pupae/person, but there was apparently no dengue transmission. Barrera [41], in Puerto Rico, corroborates the relationship between these variables, citing a mean of $0.99 \pm 0.33$ pupae/person. Basso et al., [32] found 0.12 pupae/person in Paraguay. More recently, in a dengue transmission area of São Paulo State, in the region of São José do Rio Preto, 0.15 pupae/person were recorded [42].

In our study, the number of Ae. aegypti females captured in intradomiciliary and peridomiciliary premises was positively correlated with the number of residents, and the number was higher in intradomiciliary premises. These results indicate that this mosquito's spatial distribution was affected by resident density/house; females of this mosquito maintain a close relationship with humans, and this proximity is favoured by places with shelter, among other aspects. These data suggest that the number of residents is a factor that attracts females to the residential environment, because the blood meal supply is larger. Getis et al. [43] and Harrington et al. [34] reported that people, instead of mosquitoes, may be the main mechanism of dengue virus transmission within and/or between communities. In a study in Hawaii using a spatiotemporal approach addressing the vector habitat and dengue, the authors concluded that human population density and urbanization are risk factors for dengue propagation [44]. Lin \& Wen [45], in studying the relationships among mosquitoes, human density, and dengue incidence, found that a small number of Ae. aegypti females in a densely populated area may be sufficient to cause an outbreak of the disease, because a higher human density provides high vector contact rates. 
Over time in the urban space, Ae. aegypti has adapted to its circumstances, because the environmental and social conditions are adequate for its proliferation and dispersal. Climatic conditions seem to promote increased geographical distribution of vectors, causing the expansion of some diseases [14].

In the present study, the association between the number of Ae. aegypti females and total rainfall or mean rainfall showed that rainfall affected the number of females collected in the residences; this effect was greater in the peridomiciliary premises. In regions with constant rainfall, such as the municipality studied here, extradomiciliary premises are not good places for adults to shelter, because they are more vulnerable to the weather. Thus, it can be deduced that when it rains, mosquitoes tend to find shelter in the vicinity of their breeding grounds; thus, they move toward more sheltered places. In a study performed in Puerto Rico [46], it was shown that Ae. aegypti is sensitive to changes in rainfall and that local climatic differences can contribute to dengue transmission.

In this study, minimum temperature was an important variable in determining the number of Ae. aegypti females captured in intradomiciliary and peridomiciliary premises. Câmara et al. [47], in a study performed in the city of the Rio de Janeiro, Brazil, showed an association between temperature and infestation by Ae. aegypti. They found that minimal temperatures recorded in the years of epidemics were higher, thus indicating that temperature is a limiting factor for virus multiplication in the vector organism. In the same city, Honório et al., [37] found that both temperature and rainfall were significantly related to Ae. aegypti abundance.

Regarding Ae. albopictus, although its occurrence was reduced, some aspects deserve to be mentioned to not overlook its potential role in transmitting arboviruses. Martins et al. [48] reported the first natural evidence of the vertical transmission of the dengue virus in populations of Ae. aegypti and Ae. albopictus collected in Fortaleza (CE), Brazil and opened a discussion about the epidemiological importance of this mechanism of viral transmission in the local scenario, especially concerning DEN virus management during inter-epidemic periods. In a study of the geographic expansion of these species, it was suggested that the abundance of the Ae. albopictus population decreased when Ae. aegypti was established [20].

Serpa et al. [49] showed the predominance of Ae. aegypti in São Sebastião (SP), the same municipality as the present study, whereas Ae. albopictus was found in very small numbers. The authors reveal the occurrence of an apparent habitat segregation process resulting from an urban gradient of occupation by these species.

\section{Conclusions}

In conclusion, Ae aegypti is well established in the urban area studied, presenting itself as permanent population with higher numbers inside houses. The female density was directly proportional to the number of people in the houses, from which one can infer a higher probability of the transmission and spread of DEN viruses at the local level. However, it is evident that the risk thresholds may be different at different sites and under different contexts. Similarly, rainfall and temperature were positively correlated with the number of females collected in the residences. The adult population of Ae. aegypti was easily sampled with the aspiration method throughout the study period. Our conclusion is that the entomological indicators of adult females must be part of an interconnected data set when evaluating and controlling this mosquito.

\section{Abbreviations}

F/R: The number of females/resident; AHI: The adult house index; F/H: Adult female density/house.

\section{Competing interests}

The authors declare they have no competing interests and the sponsors had no role in the study design, data collection and analysis, decision to publish, or preparation of the manuscript: Density of Aedes aegypti and Aedes albopictus and its association with number of residents and meteorological variables in the home environment of dengue endemic area, São Paulo, Brazil.

\section{Authors' contributions}

MRM: study design, experimental design, data collection, analysis of results, and preparation and writing of the manuscript. GRAMM: overseeing the master's thesis, participation in analysis of results, preparation and writing of the manuscript, and critical review of the scientific content. LLNS: participation in article preparation, critical review of the scientific content, and writing of the manuscript. MBA: operational coordination of the field activities for collecting the material, critical review of the scientific content, and writing of the manuscript. VRA: critical review of the scientific content and writing of the manuscript. GLB: general coordination of the database, critical review of the scientific content, and writing of the manuscript. JCV: statistical analysis, critical review of the scientific content, and writing of the manuscript. VLCL: general coordination of the study, critical review of the scientific content, and writing of the manuscript. All authors read and approved the final version of the manuscript

\section{Acknowledgements}

This study was supported by the Superintendência de Controle de Endemias (Sucen) under grant agreement $n^{\circ}$ 000005/2011 and a Fundação de Amparo à Pesquisa do Estado de São Paulo (FAPESP) under grant agreement n 53123-7/ 2009. The authors thank the field team from the Sucen-SR3 (sector 4) for operational support for the eggs sampling.

\section{Author details}

'Superintendência de Controle de Endemias, Praça Coronel Vitoriano, 23 Jardim Santa Clara, Centro, Taubaté, São Paulo CEP 12020-020, Brasil.

Universidade de Taubaté, Avenida Tiradentes, 500, Bom Conselho, Taubaté, São Paulo CEP 12030-180, Brasil. ${ }^{3}$ Superintendência de Controle de Endemias, Rua Paula Souza, 166, Luz, São Paulo, São Paulo CEP 01027-000, Brasil. ${ }^{4}$ Superintendência de Controle de Endemias, Rua São Carlos, 546, Campinas, São Paulo CEP 13035-420, Brasil.

Received: 28 August 2014 Accepted: 27 January 2015

Published online: 19 February 2015 


\section{References}

1. Lambrechts $L$, Failloux $A B$. Vector biology prospects in dengue research. Mem Inst Oswaldo Cruz. 2012;107:1080-2. doi:10.1590/S007402762012000800022 .

2. Lima-Camara TN, Honório NA, Lourenco-de-Oliveira R. Frequency and spatial distribution of Aedes aegypti and Aedes albopictus (Diptera, Culicidae) in Rio de Janeiro, Brazil. Cad Saúde Pública. 2006;22:2079-84.

3. Martins VEP, Alencar CH, Kamimura MT, Araujo FMC, Simone SG, Dutra RF, et al. Occurrence of natural vertical transmission of dengue-2 and dengue-3 viruses in Aedes aegypti and Aedes albopictus in Fortaleza, Ceará, Brazil. PLoS One. 2012;7:e41386.

4. World Health Organization. Dengue: Guidelines for diagnosis, treatment, prevention and control: WHO, Geneva, Switzerland. 1-160. Available: http://www.ncbi.nlm.nih-gov/books/NBK143157

5. Gomes AC, Nunes Da Silva N, Bernal RTI, Leandro AS. Estimação da infestação predial por Aedes aegypti (Díptera: Culicidae) por meio da armadilha Adultrap. Epid Serv Saúde Brasília. 2008;17:293-300. doi:10.5123/ S1679-49742008000400006

6. Maciel-de-Freitas R, Aguiar R, Bruno RV, Guimarães MC, Lourenço-de-Oliveira $R$, Sorgin MHF, et al. Why do we need alternative tools to control mosquitoborne diseases in latin america? Mem Inst Oswaldo Cruz. 2012;107:828-9. doi:10.1590/S0074-02762012000600021.

7. Azil AH, Li M, Williams CR. Dengue vector surveillance programs: A review of methodological diversity in some endemic and epidemic countries. Asia Pac J Public Health. 2013;23:827-42.

8. Focks DA. A Review of Entomological Sampling Methods and Indicators for Dengue Vectors. Gainesville, FL: UNICEF/UNDP/WORLD BANK/WHO Special Programme for Research and Training in Tropical Diseases (TDR); 2003.

9. Barata EAMF, Chiaravalloti Neto F, Dibo MR, Macoris MLG, Barbosa AAC, Natal D, et al. Captura de culicídeos em área urbana: avaliação do método das caixas de repouso. Rev Saude Publica. 2007;41:375-82.

10. Resende MC, Azara TMF, Costa IO, Heringer LC, Andrade MR, Acebal JL, et al. Field optimisation of mosquiTRAP sampling for monitoring Aedes aegypti Linnaeus (Diptera: Culicidae). Mem Inst Oswaldo Cruz. 2012;107:294-302.

11. Bowman LR, Runge-Ranzinger $S, M c C$ all PJ. Assessing the relationship between vector indices and dengue transmission: a systematic review of the evidence. PLoS Negl Trop Dis. 2014;8:e2848.

12. Nguyen $T$, Luu L, Vu T, Buisson $Y$. Increase of entomological indices during the pre-epidemic period of dengue in Ben Tre, South Vietnam. Bull Soc Pathol Exot. 2011;104:313-20.

13. Sivagnaname N, Gunasekaran K. Need for an efficient adult trap for the of dengue vectors. Indian J Med Res. 2012;136:739-49.

14. Reiter P. Climate change and mosquito-borne disease. Environ Health Perspect. 2001;109:141-61.

15. Brady OJ, Johansson MA, Guerra CA, Bhatt S, Golding N, Pigott DM, et al. Modelling adult Aedes aegypti and Aedes albopictus survival at different temperatures in laboratory and field settings. Parasit Vectors. 2013;6:351. doi:10.1186/1756-3305-6-351.

16. Eisen L, Monaghan AJ, Lozano-Fuentes S, Steinhoff DF, Hayden MH, Bieringer PEJ. The impact of temperature on the bionomics of Aedes (Stegomyia) aegypti, with special reference to the cool geographic range margins. Med Entomol. 2014;51:496-516.

17. Barrera R, Amador M, MacKay AJ. Population dynamics of Aedes aegypti and dengue as influenced by weather and human behavior in San Juan, Puerto Rico. PLoS Negl Trop Dis. 2011;5:e1378.

18. Instituto Brasileiro de Geografia e Estatística (IBGE). Censo demográfico 2013: domicílios de São Sebastião - SP http://cidades.ibge.gov.br/xtras/perfil. php?codmun $=355070$

19. SUCEN. Manual de Vigilância Entomológica de Aedes aegypti. São Paulo: SUCEN; 1997.

20. Passos RA, Marques GRAM, Condino LMF, Voltolini JC. Dominância de Aedes aegypti sobre Aedes albopictus no litoral sudeste do Brasil. Rev Saude Publica. 2003;37:729-34.

21. CVE/SES/SP. Distribuição dos casos confirmados de dengue até 2013. http://www.cve.saude.sp.gov.br/htm/zoo/dengue_dados.html

22. Nasci RS. A lightweight battery-powered aspirator for collecting resting mosquitoes in the field. Mosq News. 1981;41:808-11.

23. Romero-Vivas CME, Falconar AKI. Investigation of relationships between Aedes aegypti egg, larvae, pupae, and adult density indices where their main breeding sites were located indoors. J Am Mosq Control Assoc. 2005;21:15-21.
24. Tun Lin W, Kay BH, Barnes A, Forsyth S. Critical Examination of Aedes aegypti indices: correlations with abuncance. Am J Trop Med Hyg. 1996;54:543-7.

25. Rodriguez-Figueroa L, Rigau-Perez JG, Suarez EL, Reiter P. Risk factors for dengue infection during an outbreak in Yanes, Puerto Rico, in 1991. Am J Trop Med Hyg. 1995;52:496-502.

26. Forattini OP, Culicideologia Médica. Identificação, Biologia e Epidemiologia, vol. 2. Edusp: São Paulo; 2002.

27. El-Bradley AA, Al-Ali KH. Prevalence and seasonal distribution of dengue mosquito, Aedes aegypti (Diptera: Culicidae) in Al-Madinah Al-unawwarah, Saudi Arabia. J Entomol. 2010;7:80-8.

28. Fávaro EA, Dibo MR, Mondini A, Ferreira AC, Barbosa AAC, Eiras AE, et al. Physiological state of Aedes (Stegomyia) aegypti mosquitoes captured with MosquiTRAP in Mirassol, São Paulo, Brazil. J Vector Ecol. 2006;31:285-91.

29. Dibo MR, Menezes RMT, Ghirardelli CP, Mendonça AL, Neto FC. The presence of culicidae species in medium-sized cities in the State of São Paulo, Brazil and the risk of west nile fever and other arbovirus infection. Rev Soc Bras Med Trop. 2011;44:496-503.

30. Williams CR, Johnson PH, Ball TS, Ritchie SA. Productivity and population density estimates of the dengue vector mosquito Aedes aegypti (Stegomyia aegypti) in Australia. Med Vet Entomol. 2013;27:313-22.

31. Walker KR, Joy TK, Ellers-Kirk C, Ramberg FB. Human and environmental factors affecting Aedes aegypti distribution in an arid urban environment. J Am Mosq Control Assoc. 2011;27:135-41. doi:10.2987/10-6078.1.

32. Basso C, Caffera RM, García Da Rosa E, Lairihoy R, Gonzalez C, Norbis W, et al. Mosquito-producing containers, spatial distribution, and relationship between Aedes aegypti population indices on the southern boundary of its distribution in South America (Salto, Uruguay). Am J Trop Med Hyg. 2012;87:1083-8.

33. Marteis LS, Steffler LM, Araújo KCGM, Santos RLC. Identificação e distribuição espacial de imóveis chave de Aedes aegypti no bairro Porto Dantas, Aracaju, Sergipe, Brasil entre 2007 e 2008. Cad Saúde Pública. 2013;29:368-78.

34. Harrington LC, Scott TW, Lerdthusnee K, Coleman RC, Costero A, Clark GG, et al. Dispersal of the dengue vector Aedes aegypti within and between rural communities. Am J Trop Med Hyg. 2005;72:209-20.

35. Chan KL. Singapore's dengue hemorrhagic fever control programme: a case study on the successful control of Aedes aegypti and Aedes albopictus using mainly environmental measures as part integrated vector control. Ministry of Health of Singapore 1985

36. Barata EA, Costa Al, Chiaravalloti Neto F, Glasser CM, Barata JM, Natal D. Aedes aegypti (I.) population in an endemic área of dengue in Southeast Brazil. Rev Saude Publica. 2001;35:237-42.

37. Scott TW, Takken W. Feeding strategies of anthropophilic mosquitoes result in increased risk of pathogen transmission. Trends Parasitol. 2012;28:114-21.

38. Honório NA, Codeço CT, Alves FC, Magalhães MA, Lourenço-De-Oliveira R. Temporal distribution of Aedes aegypti in different districts of Rio de Janeiro, Brazil, measured by two types of traps. J Med Entomol. 2009;46:1001-14. doi:10.1603/033.046.0505

39. Chen YR, Hwang JS, Guo YJ. Ecology and control of dengue vector mosquitoes in Taiwan. Gaoxiong Yi Xue Ke Xue Za Zhi. 1994;10:S78-87.

40. Chadee DD. Dengue cases and Aedes aegypti indices in Trinidad, West Indies. Acta Trop. 2009;112:174-80.

41. Barrera R. Simplified pupal surveys of Aedes aegypti (L.) for entomologic surveillance and dengue control. Am J Trop Med Hyg. 2009;81:100-7.

42. Fávaro EA, Dibo MR, Pereira M, Chierotti AP, Rodrigues-Junior AL, Chiaravalloti-Neto F. Indicadores entomológicos de Aedes aegypti en área endêmica de dengue, São Paulo, Brasil. Rev Saude Publica. 2013:47:88-97.

43. Getis A, Morrison AC, Gray K, Scott TW. Characteristics of the spatial patterns of the dengue vector, Aedes aegypti, in lquitos, Peru. Am J Trop Med Hyg. 2003;69:494-505

44. Kolivras KN. Mosquito habitat and dengue risk potential in Hawaii: a conceptual framework and GIS application. Prof Geogr. 2006;58:139-54.

45. Lin CH, Wen TH. Using geographically weighted regression (GWR) to explore spatial varying relationships of immature mosquitoes and human densities with the incidence of dengue. Int J Environ Res Public Health. 2011;8:2798-815

46. Johansson MA, Dominici F, Glass GE. Local and global effects of climate on dengue transmission in Puerto Rico. PLoS Negl Trop Dis. 2009;3:e382.

47. Câmara FP, Gomes AF, Santos GT, Câmara DCP. Clima e epidemias de dengue no estado do Rio de janeiro. Rev Soc Bras Med Trop. 2009;42:137-40. 
48. Martins VEP, Alencar CH, Kamimura MT, Araujo FMC, Simone SG, Dutra RF, et al. Occurrence of natural vertical transmission of dengue-2 and dengue-3 viruses in Aedes aegypti and Aedes albopictus in Fortaleza, Ceará. Brazil PLoS ONE. 2012;7:e41386. doi:10.1371/journal.pone.0041386.

49. Serpa LLN, Marques GRAM, Lima AP, Voltolini JC, Arduino MB, Barbosa GL, et al. Study of the distribution and abundance of the eggs of Aedes aegypti and Aedes albopictus according to the habitat and meteorological variables, municipality of São Sebastião, São Paulo State. Brazil Parasit Vectors. 2013;6:321. doi:10.1186/1756-3305-6-321.

\section{Submit your next manuscript to BioMed Central} and take full advantage of:

- Convenient online submission

- Thorough peer review

- No space constraints or color figure charges

- Immediate publication on acceptance

- Inclusion in PubMed, CAS, Scopus and Google Scholar

- Research which is freely available for redistribution 